\title{
CORRELATION BETWEEN ECHOCARDIOGRAPHIC PARAMETERS OF LEFT VENTRICLE AND GLYCOSYLATED HEMOGLOBIN IN CHILDREN WITH TYPE 1 DIABETES MELLITUS
}

\author{
Valeriu ESANU, Ina PALII \\ Nicolae Testemițanu State University of Medicine and Pharmacy, Republic of Moldova \\ PHMI Institute of Mother and Child, Chisinau, Republic of Moldova
}

Corresponding author: Valeriu Esanu, e-mail: esanu_valeriu@yahoo.fr

DOI: $10.38045 /$ ohrm.2022.1.06

CZU: [616.124.2-073.43+616-074]:616.379-008.64-053.2

Keywords: children, Diabetes Mellitus, left ventricle, glycosylated hemoglobin.

Cuvinte cheie: copii, diabet zaharat, ventricul stâng, hemoglobină glicozilată.
Introduction. Deterioration of left ventricular (LV) parameters in Diabetes Mellitus (DM) can occur in the absence of other heart problems. An association between glycosylated hemoglobin (HbA1c) and changes of the LV parameters in DM has been reported. However, data regarding this association model in children with Type 1 Diabetes Mellitus (T1DM) are limited. The purpose of the work was to investigate the association between HbA1c and the LV parameters in pediatric patients.

Material and methods. The study was conducted on 28 children with T1DM ((aged 10-18 years, gender $M(15) / F$ (13), duration $\geq 5$ years). The clinical (standard medical examination) and paraclinical (biochemical dosage - HbA1c, echocardiography - LV functional and structural parameters) data was carried out. Statistical analysis used the SPSS version 20.

Results. The correlational study between the HbA1c and the LV parameters revealed a statistically significant positive correlation coefficient with aortic root diameter $(\mathrm{mm})\left(r=0.7^{* *}\right.$, $p<0.001)$, left atrium ( $\mathrm{mm})\left(r=0.8^{* *}, p<0.001 \mathrm{LV}\right.$ diastolic diameter $(\mathrm{mm})\left(r=0.7^{* *}, p<0.001\right)$, $L V$ systolic diameter $(\mathrm{mm})\left(r=0.7^{* *}, p<0.001\right)$, septal wall thickness $(\mathrm{mm})\left(r=0.5^{*}, p=0.036\right)$, posterior wall thickness $(\mathrm{mm})\left(r=0.5^{*}, p=0.032\right), \mathrm{LV}$ diastolic volume $(\mathrm{ml})\left(r=0.5^{*}, p=0.025\right)$, $L V$ systolic volume $(\mathrm{ml})\left(r=0.6^{* *}, p=0.01\right)$, ejection fraction (\%) $\left(r=0.7^{* *}, p=0.001\right)$, fractional shortening (\%) $\left(r=0.6^{* *}, p=0.002\right)$.

Conclusions. The results of the study show that in children with T1DM, the increase value of the HbA1c is associated with a consensual and proportional increase in the values of the parameters of the left ventricle.

\section{CORELATIA DINTRE PARAMETRII ECOCARDIOGRAFICI AI VENTRICULULUI STÂNG ȘI HEMOGLOBINA GLICOZILATĂ, LA COPIII CU DIABET ZAHARAT TIP 1}

Introducere. Deteriorarea parametrilor ventriculului stâng (VS) în diabetul zaharat (DZ) poate exista în absența altor probleme cardiace. A fost raportată o asociere între valorile hemoglobinei glicozilate (HbA1c) și modificările parametrilor VS în DZ. Cu toate acestea, datele privind acest model de asociere la copiii cu DZ de tip 1 (DZ1) sunt limitate. Scopul lucrării rezidă în studierea asocierii dintre HbA1c și parametrii VS la pacienții pediatrici. Material și metode. În studiu au fost incluși 28 de copii cu DZ1 (cu vârsta de 10-18 ani, gender $M(15) / F(13)$, durata $\geq 5$ ani). $S$-a efectuat evaluare clinică (examen medical standard) și paraclinică (dozare biochimică - $H b A 1 c$, ecocardiografie - parametrii funcționali și structurali ai VS). Analiza statistică - versiunea 20 SPSS.

Rezultate. Studiul corelațional dintre HbA1c și parametrii VS a relevat un coeficient de corelație pozitiv semnificativ statistic, cu diametrul aortei $(\mathrm{mm})\left(r=0,7^{* *}, p<0,001\right)$, atriul stâng ( $\mathrm{mm})\left(r=0,8^{* *}, p<0,001\right)$ diametrul diastolic al VS (mm) $\left(r=0,7^{* *}, p<0,001\right)$, diametrul sistolic al VS ( $\mathrm{mm})\left(r=0,7^{* *}, p<0,001\right)$, septul interventricular $(\mathrm{mm})\left(r=0,5^{*}, p=0,036\right)$, peretele posterior al VS ( $\mathrm{mm})\left(r=0,5^{*}, p=0,032\right)$, volumul diastolic al VS ( $\left.\mathrm{ml}\right)\left(r=0,5^{*}, p=0,025\right)$, volumul sistolic al VS (ml) $\left(r=0,6^{* *}, p=0,01\right)$, fracția de ejecție (\%) ( $\left.r=0,7^{* *}, p=0,001\right)$, fracția de scurtare (\%) $\left(r=0,6^{* *}, p=0,002\right)$.

Concluzii. Rezultatele studiului au demonstrat că la copiii cu diabet zaharat de tip 1, creșterea valorii HbA1c este asociată cu o mărire consensuală și proporțională a valorilor parametrilor ventriculului stâng. 


\section{INTRODUCTION}

The number of children with Diabetes Mellitus (DM) is increasing every year. In populations of European origin, nearly all children with DM have T1DM, but in other populations (e.g. Japan) T2DM is more common than T1DM in this age group. It is estimated that the incidence of T1DM among children is increasing in many countries particularly in those aged less than 15 years. The overall annual increase is estimated to be around $3 \%$ with strong indications of geographic differences. Generally, 1.110.100 children younger than 20 years are estimated to have T1DM globally, and around 98.200 children under the age of 15 years are diagnosed with T1DM annually, while this estimated number increases to 128.900 when the age range extends to under 20 years (1).

Diabetes Mellitus, and the continuum of blood glucose levels even below the DM diagnostic threshold are associated with a wide range of cardiovascular conditions that collectively comprise the largest cause of both morbidity and mortality for people with DM (2). Systematic reviews indicate that the relative risk of cardiovascular diseases (CVD) is between 1.6 and $2.6 \%$, but that the relative risk is higher among those of younger age. One of the common presentations of CVD in T1DM is deterioration of left ventricular (LV) parameters $(3,4)$. An association between glycosylated hemoglobin (HbA1c) and changes of the LV parameters in DM has been reported in the adult population, however, data regarding this association model in children with T1DM are limited.

Purpose of the study: while considering the aforementioned arguments and the impact of childhood health on further adult health, we considered choosing the following research on investigating the association between $\mathrm{HbA1c}$ and the LV parameters in pediatric patients with T1DM, that will contribute to the opening of new perspectives for identifying a single and effective approach, as well as for preventing cardiovascular complications of this disease to reduce the morbidity and mortality rates at a young age.

\section{MATERIAL AND METHODS}

The study project was carried out within the PHMI Mother and Child Institute, at the Department of Pediatrics of the Pediatric endocrinology clinic, in the city of Chisinau, the Republic of Moldova, to which 28 children with DM were admitted, aged from 10 to 17 years 11 months and 29 days, from both urban and rural areas, the patients being selected electively between November 2018 and February 2021.

The research comprised several stages. The 1st stage included 28 children with DM, who were selected based on the inclusion/exclusion criteria, and made up the research group by the following criteria: the age of 10-17 years 11 months and 29 days (inclusive); with T1DM and received insulin therapy only; the child's parent or guardian consent, as well as children's assent (age $\geq 14$ years) on research participation; being a citizen of the Republic of Moldova; ability to effectively communicate with the researcher; ability to understand and follow the study requirements; sufficient understanding in signing the informed agreement and written assent.

The study exclusion criteria for the patients were the following: T2DM, hypertension, cardiomyopathy, valvular and congenital heart disease, having a suggestive clinical examination, confirmed by specialized examinations; acute conditions, whether or not accompanied by fever, whether or not undergoing treatment, chronic respiratory, cardiovascular, gastrointestinal, renal, neurological, endocrine, etc., disorders, whether or not undergoing treatment; the child's parents or legal representative disagreement, child's refusal to participate in the research, low compliance, patient's refusal to be included in the study.

In the 2nd stage the participants underwent an examination, which included the clinical (standard medical examination) and paraclinical (biochemical dosage - HbA1c, echocardiography LV functional and structural parameters) data.

The 3rd stage included a statistical analysis of the obtained results. Practical conclusions and recommendations, based on the obtained results, were traced out in the 4 th stage of the study.

All the participants were selected and informed about the research stages, being enrolled only based on personal agreement, following a detailed explanation on the requirements and procedures of necessary investigations by discussing with each subject individually. All the procedures were performed, based on children's parent and legal representative consent, as well as 
on written assent of children $\geq 14$ years old. They were not paid and have not suffered any financial costs for participation.

Anthropometry. Weight was measured using weighing scales to the nearest $0.1 \mathrm{~kg}$. Height was measured using a stadiometer and was expressed in centimeters with no decimal. Body mass index (BMI) was calculated as weight divided by the square of height $\left(\mathrm{kg} / \mathrm{m}^{2}\right)$. BMI was categorized according to the Centers for Disease Control and Prevention (CDC) age - and sexspecific growth charts. The following categories were used: underweight: $<5$ th percentile, normal weight: 5 th to 85 th percentile, overweight: 85 th to 95 th percentile, and obese: $>95$ th percentile, and BMI ranging from -2 standard deviations (SD) to less or equal to + 1 SD (which corresponds to BMI $25 \mathrm{~kg} / \mathrm{m}^{2}$ at 19 years); overweight was defined as BMI less than +2 SD (which corresponds to BMI $30 \mathrm{~kg} / \mathrm{m}^{2}$ at 19 years), obese as BMI >+2 SD, and underweight as <-2 SD (5). Body surface area (BSA, Dubois formula) $-0.20247 \mathrm{x}$ height $(\mathrm{m})^{0.725} \mathrm{x}$ weight $(\mathrm{kg})^{0.425}(6)$.

Blood pressure (BP). Points that were taken into account during the measurement: before measuring BP, the child should be placed in a comfortable position for 3-5 minutes. The measurement had to be performed in the right arm and at the level of the heart. The height of the extended part of the cuff should cover $80-100 \%$ of the circumference of the arm, and the width - at least $40 \%$ of the circumference of the arm. The lower end of the cuff should be placed $2-3 \mathrm{~cm}$ above the antecubital fossa, and the stethoscope should be placed on the brachial artery. BP was estimated with an automatic electronic sphygmomanometer (Omron M7 Intelli IT, Vietnam). BP was determined through systolic blood pressure (SBP) and diastolic blood pressure (DBP) readings in mmHg. The measurement was made three times, with a five-minute interval between measurements, using the average of the last two. The procedure was carried out following the recommendations of the American Academy of Pediatrics (AAP) and European Society of Hypertension (ESH). The classification was made following the criteria proposed by the AAP and ESH, which establishes the percentiles of SBP and DBP for sex, age, and size. According to AAP, and ESH guidelines, a BP value below the 90th percentile by age, sex, and height is considered as normal BP. Arterial Hypertension ( $\mathrm{AH}$ ) is defined as a systolic and/or diastolic blood pressure measured clinically at or above the 95th percentile (7, 8).

The high blood pressure in adults guideline (American Heart Association and American College of Cardiology) is recommended to be used for individuals aged 13 years and older by the AAP guideline and for individuals aged 16 years and above by the ESH guideline (9).

Laboratory analyses. HbA1c was performed in the Mother and Child Institute's laboratory. The patients were classified according to ISPAD 2018 (International Society for Pediatric and Adolescent DM) guidelines which consider HbA1c < $7.5 \%$ to be the level for optimal control (10).

Insulin dosage. The insulin requirement was calculated according to standard protocol (1 $\mathrm{U} / \mathrm{kg} /$ day) (11).

Cardiovascular evaluation. According to the American Society of Echocardiography (ASE) pediatric guidelines (12), two-dimensional guided M-mode echocardiograms were obtained from all children with T1DM. The data of interest in echocardiography (EcoCG) were left ventricle (LV) systolic and diastolic function parameters, LV mass index (LVMI), left ventricular geometry, and aortic root measurements. Left ventricular ejection fraction (EF) and shortening fraction (SF) were used as measurements of LV systolic function; EF was calculated using the biplane Simpson method in the apical views of the heart as recommended by the ASE. SF was calculated in the parasternal short-axis views using $M$ mode data. The other M-mode measurements calculated include interventricular septal thickness in diastole, LV end-diastolic dimension, the posterior wall thickness at the end diastole, and LV end-systolic dimension. The relative wall thickness and indexed LV mass was also calculated using the above M-mode measurements. RWT was calculated using the formula $(2 \times$ PWd)/LVEDD. The LV mass was calculated using the Devereux formula (13). The LVMI was then calculated by dividing the calculated LV mass in grams by the patient's height (in meters) raised to the power of 2.7 ( LVMI = left ventricular mass (g)/height (m) $)^{2.7}$ ).

The diameter of the aortic root was calculated in the parasternal long-axis views during systole. It represents the maximal diameter of the aorta at the level of the sinuses of Valsalva (12). 
Definitions of EcoCG data. LVH is defined as LVMI of greater than 95th percentile for age and gender (14). Using LVMI and RWT, LV geometry is generally classified into four patterns: normal geometry: normal LVMI and RWT; concentric remodeling: normal LVMI and increased RWT; eccentric LV hypertrophy: increased LVMI and normal RWT; and concentric LV hypertrophy: increased LVMI and RWT (15).

Z-scores of cardiac structures/Detroit data. Calculate the z-scores of cardiac structures (EcoCG) was related to body surface area (6).

Ethics. The study complied with the international standards of medical ethics, developed by the Declaration of Helsinki, regarding confidentiality and personal data protection of the participants. The research was approved by the Research Ethics Committee of Nicolae Testemitanu State University of Medicine and Pharmacy (report no. 42 of 17.06.2019). The resulting data were revealed only to the concerned participant, the personal data of each subject were not used and will not be used for any other purpose. The research was conducted according to the principles of the Declaration of Helsinki.

Statistics. The data collected from the primary material were introduced in the electronic database. Data were analyzed using the Statistical Package for the Social Sciences program (IBM-
SPSS) version 20. Descriptive statistics presented as frequencies, proportions (\%), mean and standard deviation according to the variable type. Level of significance was set at $\leq 0.05$ to be significant difference or correlation.

\section{RESULTS}

Characteristics. There were 28 children with T1DM (duration of T1DM $\geq 5$ years; absence of $\mathrm{AH}$, insulin therapy) enrolled in the study, the mean age of the patients was $13.7 \pm 2.35$ (male patients were 15 (56.7\%), female 13 (43.3\%)).

The results of the selective analysis of anthropometric, hemodynamic and biochemical parameters.

The studied group was characterized by the following values (tab. 1): weight $(\mathrm{kg})=53.0 \pm 17.0$ (according to the percentiles $-5^{\text {th }}$ to $<85^{\text {th }}$ ), height $(\mathrm{cm})=157.2 \pm 36.7$ (according to the percentiles -5 th to $\left.<85^{\text {th }}\right)$, body mass index $\left(\mathrm{kg} / \mathrm{m}^{2}\right)$ $=19.0 \pm 4.5$ (according to the percentiles $-5^{\text {th }}$ to $<85^{\text {th }}$, and according to the $\mathrm{Z}$ score $=-2 \geq \mathrm{z}$-score $<+1)$, and body surface area $\left(\mathrm{cm}^{2}\right)=1.52 \pm 0.3$. Systolic blood pressure $(\mathrm{mm} \mathrm{Hg})=115.7 \pm 12.3$ (according to the percentiles $<90^{\text {th }}$ ), diastolic blood pressure $(\mathrm{mm} \mathrm{Hg})=75.2 \pm 8.7$ (according to the percentiles $-<90$ th $)$, HbA1c $(\%)=9.2 \pm 2.4$ (females $>$ males, aged $>15$ years old).

Table 1 . The values of selective anthropometric, hemodynamic and biochemical parameters in children included within the research.

\begin{tabular}{|c|c|}
\hline Variable & Total $(n=28)$ \\
\hline Gender (M/F) & $15 / 13$ \\
\hline Age, $M \pm m$, (years) & $13.7 \pm 2.35$ \\
\hline Duration of T1DM, M $\pm m$, (years) & $6.51 \pm 3.2$ \\
\hline Height, $M \pm m,(\mathrm{~cm})$ & $157.2 \pm 36.7$ \\
\hline Weight, $M \pm m$, (kg) & $53.0 \pm 17.0$ \\
\hline$B M I, M \pm m,\left(\mathrm{~kg} / \mathrm{m}^{2}\right)$ & $19.0 \pm 4.5$ \\
\hline BSA, M $\pm m,\left(\mathrm{~cm}^{2}\right)$ & $1.52 \pm 0.3$ \\
\hline Systolic blood pressure, $\mathrm{M} \pm \mathrm{m},(\mathrm{mm} \mathrm{Hg})$ & $115.7 \pm 12.3$ \\
\hline Diastolic blood pressure, $\mathrm{M} \pm \mathrm{m},(\mathrm{mm} \mathrm{Hg})$ & $75.2 \pm 8.7$ \\
\hline HbA1c, $M \pm m,(\%)$ & $9.2 \pm 2.4$ \\
\hline
\end{tabular}

Note: values are presented as mean \pm standard deviation for a number of values; BMI - body mass index; BSA body surface area; HbA1c - hemoglobin A1c.

The results of the selective analysis of echocardiographic parameters of left ventricle. The studied group was characterized by the following values (tab. 2): aortic root diameter $(\mathrm{mm})=24.5 \pm 6.0$, left atrium $(\mathrm{mm})=26.8 \pm 6.2$, right atrium $^{1,2}$ $(\mathrm{mm})=29.0 \pm 7.3 / 30.1 \pm 7.2$, right ventricle $(\mathrm{mm})$
$=15.1 \pm 4.0, \mathrm{LV}$ diastolic diameter $(\mathrm{mm})=$ 41.3 \pm 9.6 , LV systolic diameter $(\mathrm{mm})=25.4 \pm 5.9$, interventricular septal thickness at end-diastole $(\mathrm{mm})=7.5 \pm 1.9$, posterior wall thickness at enddiastole $(\mathrm{mm})=7.4 \pm 1.8, \mathrm{LV}$ diastolic volume $(\mathrm{ml})=81.9 \pm 24.6, \mathrm{LV}$ systolic volume $(\mathrm{ml})=$ 
25.2 \pm 7.7 , ejection fraction $(\%)=65.7 \pm 14.8$, fractional shortening $(\%)=36.7 \pm 8.4$, LV Mass $(\mathrm{g})=$ 104.1 \pm 21.6 , LV Mass Index $\left(\mathrm{g} / \mathrm{m}^{2}\right)=27.06 \pm 4.4$ (and with right atrium ${ }^{1,2}(\mathrm{~mm}) \quad\left(\mathrm{r}=0.6^{* *}\right.$, $\mathrm{p}=0.003)$, right ventricle $(\mathrm{mm}) \quad\left(\mathrm{r}=0.6^{* *}\right.$, $\mathrm{p}=0.003)$, (height $(\mathrm{cm})\left(\mathrm{r}=0.7^{* *}, \mathrm{p}<0.001\right)$, weight $(\mathrm{kg})\left(\mathrm{r}=0.5^{*}, \mathrm{p}<0.5\right)$, body mass index $\left(\mathrm{kg} / \mathrm{m}^{2}\right)\left(\mathrm{r}=0.5^{*}, \mathrm{p}<0.5\right)$, systolic BP and diastolic $\mathrm{BP}(\mathrm{mm} \mathrm{Hg})$ ). Diastolic function of LV has not been studied, being considered a research limitation.

Z-scores of cardiac structures/Detroit data. Aortic root diameter $=+3.0$, left atrium $(\mathrm{mm})=+0.62$, right ventricle $=-1.31, \mathrm{LV}$ diastolic diameter $=$ -0.75 , LV systolic diameter $=-0.67$, interventricular septal thickness at end-diastole $=+0.24$, posterior wall thickness at end-diastole $=+0.63, \mathrm{LV}$ Mass $(\mathrm{g})=-0.59$.

The results of the evaluation of the types of remodeling of the left ventricular myocardium. The types of pathological remodeling were distributed as follows: $5.0 \%(n=2)$ - concentric LV hypertrophy, $5.0 \%(\mathrm{n}=2)$ - concentric $\mathrm{LV}$ remodeling and $5.0 \% \quad(\mathrm{n}=2)$ - eccentric LV hypertrophy $((85.0 \%(n=22)$ participants showed a normal LV geometry pattern).

Table 2. The values of selective EcoCG parameters, in particular parameters for LV myocardial remodeling in children included within the research.

\begin{tabular}{|c|c|}
\hline Variables & Total $(n=28)$ \\
\hline LA (mm) & $26.8 \pm 6.2$ \\
\hline RA1 (mm) & $29.0 \pm 7.3$ \\
\hline RA2 (mm) & $30.1 \pm 7.2$ \\
\hline $\mathrm{RV}(\mathrm{mm})$ & $15.1 \pm 4.0$ \\
\hline RWT (mm) & $7.5 \pm 1.9$ \\
\hline IVSd (mm) & $7.5 \pm 1.9$ \\
\hline LV Mass (g) & $104.1 \pm 21.6$ \\
\hline LV Mass Index $\left(\mathrm{g} / \mathrm{m}^{2}\right)$ & $27.06 \pm 4.4$ \\
\hline PWd (mm) & 7.4 \pm 1.8 \\
\hline LVEDD (mm) & $41.3 \pm 9.6$ \\
\hline LVESD (mm) & $25.4 \pm 5.9$ \\
\hline LVEDV (ml) 3b, & $81.9 \pm 24.6$ \\
\hline LVESV (ml) & $25.2 \pm 7.7$ \\
\hline LVFS (\%) & $36.7 \pm 8.4$ \\
\hline LVEF (\%) & $65.7 \pm 14.8$ \\
\hline
\end{tabular}

Note: values are presented as mean \pm standard deviation for numerical data; LA - left atrium; RA - right atrium; IVSd - interventricular septal thickness at end-diastole; PWd - posterior wall thickness at end-diastole; LVEDD left ventricular end - diastolic diameter; LV Mass - left ventricular mass; RWT - left ventricular relative posterior wall thickness; LVESD - left ventricular end - systolic diameter; LVEDV - left ventricular end - diastolic volume; LVESV - left ventricular end - systolic volume; LVMI - LV Mass Indexed to Body Surface Area; LVEF - left ventricular ejection fraction; LVFS - LV fractional shortening.

Correlation between selective EcoCG parameters of LV and glycosylated hemoglobin (fig. 1). The correlational study between the HbA1c and the LV parameters revealed a statistically significant positive correlation coefficient with aortic root diameter $(\mathrm{mm})\left(\mathrm{r}=0.7^{* *}, \mathrm{p}<0.001\right)$, left atrium (mm) $\left(r=0.8^{* *}, p<0.001\right)$, LV diastolic diameter $(\mathrm{mm})\left(\mathrm{r}=0.7^{* *}, \mathrm{p}<0.001\right)$, LV systolic diameter $(\mathrm{mm})\left(\mathrm{r}=0.7^{* *}, \mathrm{p}<0.001\right)$, interventricular septal thickness at end-diastole $(\mathrm{mm})\left(\mathrm{r}=0.5^{*}\right.$, $\mathrm{p}=0.036)$, posterior wall thickness at enddiastole $(\mathrm{mm})\left(\mathrm{r}=0.5^{*}, \mathrm{p}=0.032\right)$, LV Mass (g) $\left(\mathrm{r}=0.5^{*}, \mathrm{p}=0.038\right), \mathrm{LV}$ Mass Index $\left(\mathrm{r}=0.5^{*}\right.$, $\mathrm{p}=0.038), \mathrm{LV}$ diastolic volume $(\mathrm{ml})\left(\mathrm{r}=0.5^{*}\right.$, $\mathrm{p}=0.025), \mathrm{LV}$ systolic volume $(\mathrm{ml})\left(\mathrm{r}=0.6^{* *}\right.$, $\mathrm{p}=0.01), \quad \mathrm{LV}$ ejection fraction $(\%)\left(\mathrm{r}=0.7^{* *}\right.$, $\mathrm{p}=0.001)$, LV fractional shortening $(\%)\left(\mathrm{r}=0.6^{* *}\right.$, $\mathrm{p}=0.002)$ (and, also, with right atrium ${ }^{1,2}(\mathrm{~mm})$ $\left(\mathrm{r}=0.6^{* *}, \mathrm{p}=0.003\right)$, right ventricle $(\mathrm{mm})\left(\mathrm{r}=0.6^{* *}\right.$, $\mathrm{p}=0.003)$, (height $(\mathrm{cm})\left(\mathrm{r}=0.7^{* *}, \mathrm{p}<0.001\right)$, weight $(\mathrm{kg})\left(\mathrm{r}=0.5^{*}, \mathrm{p}<0.5\right)$, body mass index $\left(\mathrm{kg} / \mathrm{m}^{2}\right)\left(\mathrm{r}=0.5^{*}, \mathrm{p}<0.5\right)$, systolic blood pressure and diastolic blood pressure ( $\mathrm{mm} \mathrm{Hg}$ )).

\section{DISCUSSIONS}

The main cause of death in European countries is cardiovascular diseases (CVD). CVDs tend to pre 


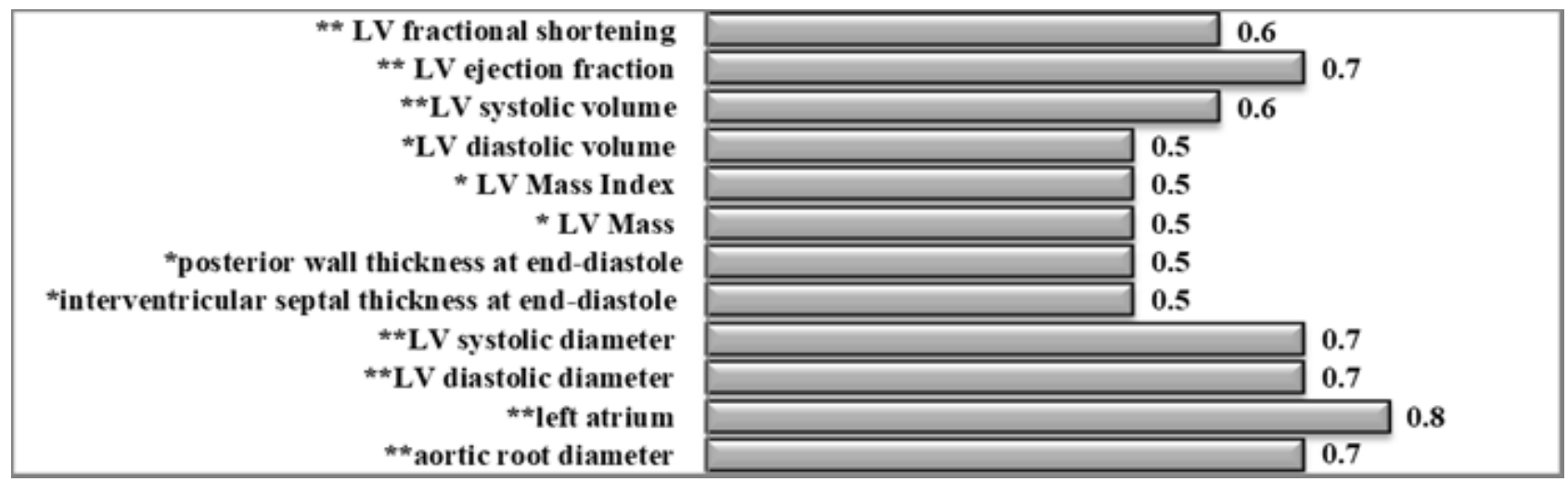

Note: ${ }^{* *} \mathrm{p}<0,001 ;{ }^{*} \mathrm{p}<0,05$.

Figure 1. Statistical correlations of HbA1c with left ventricular (LV) parameters.

sent at a younger age in patients with DM than in the general population (16). The SEARCH for Diabetes in Youth Study showed that significant complications severely affect the quality of life of DM early in their life (17). Therefore, adolescence and young adulthood are the best periods for actions to lower cardiovascular risks.

Studies on adults with T1DM were reported an association between HbA1c and changes of the LV parameters (the individuals with DM have increased LV wall thickness and mass, and impaired diastolic function in the absence of overt LV systolic dysfunction) (18). However, data regarding this association model in children with T1DM are limited.

Presumptively, the duration of DM is closely associated with the onset and severity of cardiovascular complications in T1DM (18). The duration of the disease is probably the strongest predictor for the development and progression of diabetic cardiomyopathy (structural and functional changes, in our study - was confirmed pathological LV remodeling patterns, respectively, concentric LV hypertrophy (5.0\%), concentric LV remodeling (5.0\%), and eccentric LV hypertrophy (5.0\%), systolic function - no change and diastolic function - was not performed). Besides DM duration, the magnitude of hyperglycemia is also a strong risk factor for the development and progression of cardiovascular complications.

The Diabetes Control and Complications Trial and the Epidemiology of Diabetes Interventions and Complications study showed that the progression of complications can be reduced by strict glycemic control (19). HbA1c levels less than $7.5 \%$ are recommended to reduce future complications according to the ISPAD 2018 (10). In our study, we reported a mean HbA1c of $9.2 \%$ (most of the participants were not achieving the target control, similar in other researches Ogugua C. F. et al. - 11.4\% (20), Aljuhani F. et al. $(9.7 \%)$ (21), Stankute I. et al. - 8.5\% (22)). We found that young females have worse glycemic control than males, which is consistent with other studies' results (23). Of all age groups, patients aged 15 years old have the worst glycemic control, probably because of adjustments in the endocrine system, and increased independence in DM care during adolescence makes achieving optimal HbA1c really difficult (24).

During the research, it was performed the estimation of the correlation between $\mathrm{HbA} 1 \mathrm{c}$ and selective EcoCG parameters of $L V$, in particular with LV diastolic and systolic diameter, interventricular septal thickness at end-diastole, the posterior wall thickness at end-diastole, LV Mass, LV Mass Index, LV diastolic and systolic volume. The results showed that in children with T1DM, the increased value of the HbA1c is associated with a consensual and proportional increase in the values of the parameters of the LV $(\mathrm{p}<0.05)$. In other researches, for example, in the study conducted by Bagheri M. et al. the effect of HbA1c level on increase, LV mass was not significant, only some demographic factors (age, height, weight, maximum BP) had positive and meaningful relationships with an LV posterior wall $(\mathrm{p}<0.05)$ (25), but, Seferovic J. et al. showed that the LVMI was associated with higher fasting glucose and HbA1C, (indicating the possible role of hyperglycemia in LV mass increase) (26).

Chronic increase in plasma glucose level is associated with LV mass increment. Saad I. A. et al. showed that improved glycemic control in patients with T1DM is associated with regression of septal thickness and LV mass without significant effect on systolic or diastolic function (27). Also, Weinrauch L. A. et al., in a study involving 
patients with T1DM showed improvement in measures of heart rate variation correlated with a decrease in LV mass and dimensions after 12 months follow-up and this paralleled glycemic control (28).

Increased LVMI could be a potential, presymptomatic marker of myocardial structural change in T1DM. Also, LVMI was associated with higher HbA1c, indicating the possible role of hyperglycemia in LV mass increase (26). In our study, LV ejection and shortening fraction were normal, and we found an association with $\mathrm{HbA1c}$ levels ( $\left.\mathrm{r}=0.7^{* *}, \mathrm{p}=0.001 ; \mathrm{r}=0.6^{* *}, \mathrm{p}=0.002\right)$. Indeed, the association between LV systolic function and dysglycemia has been inconsistent across previous studies. The Cardiovascular Health Study showed no association between the severity of DM and LV fractional shortening. An early analysis from the Framingham Heart Study showed a slight decrease in fractional shortening only among males (adult patients) (29). In a cardiac MRI study of 1603 Framingham Study Offspring participants, there was no association between DM and MRI-derived LV ejection fraction) (30).

On the other hand, Yilmaz S. et al. found that duration of DM had a positive significant correlation with LA $(\mathrm{r}=0.6, \mathrm{p}=0.0001)$, Ao $(\mathrm{r}=0.3$, $\mathrm{p}=0.05)$, PA $(\mathrm{r}=0.5, \mathrm{p}=0.0001)$, IVS $(\mathrm{r}=0.3$, $\mathrm{p}=0.04)$, LVEDD ( $\mathrm{r}=0.4, \mathrm{p}=0.03)$, LVESD $(\mathrm{r}=0.4$, $\mathrm{p}=0.02)$ and SV $(\mathrm{r}=0.4, \mathrm{p}=0.03)$ measured at the first time. On the other hand, no significant correlations were found between EcoCG measurements and HbA1c or insulin dose (duration of DM was significantly higher in patients with $\mathrm{LV}$ hypertrophy $(\mathrm{LVH})$, and, though there was a trend for patients with LVH to have the level of HbAlc to be higher $(9.5 \pm 0.8 \%)$ than those with- out LVH $(8.5 \pm 1.5 \%)$, this trend was not significant statistically) (31). Other authors reported that there is no correlation between HbA1c and the development of cardiovascular changes in children and adolescents with T1DM (31). On the other hand, Stakos D. A. et al. stated that T1DM is associated with cardiovascular abnormalities and early detection and treatment of these abnormalities may help to prevent the natural progression of the disease (32).

The seemingly contradictory results of various studies on the effect of glycemic control can be partly explained by the statement that diabetic cardiomyopathy appears to consist of two major components: the first being a short-term physiological adaptation to metabolic changes and could be reversible, probably can be cataloged and in the case of children in our research, because the second is degenerative changes for which the myocardium has a limited ability to repair (27).

Several limitations of the current study must be taken into account. The current study included a relatively small number of patients, although the T1DM is considered to have a high incidence rate. Another limitation was the lack of diastolic function assessment, which is a significant predictor of CVD risk.

Finally, the findings of our study highlighted that the management of T1DM should be multifaceted and most importantly include the glycemic control, and the EcoCG examination should be recommended to assess the presence of modifications of LV myocardium (structural and functional), which will allow detecting children with DM, who are at higher risk for developing cardiovascular complications.

\section{CONCLUSIONS}

1. We concluded that good glycemic control in children with T1DMs could improve some structural and functional parameters of the heart while failure to achieve glycemic control leads to their deterioration.

2. Follow up and early detection of myocardial structural and functional changes in young patients with T1DM contribute to better knowledge of diabetic cardiomyopathy and may help to prevent the natural progression of the disease.

3. We recommend that close observation should begin early and should include detection of cardiac alterations, as well as other diabetic complications. 


\section{CONFLICT OF INTERESTS}

The authors do not declare any conflict of interest.

\section{REFERENCES}

1. International Diabetes Federation. IDF Diabetes Atlas. Available from: www.diabetesatlas.org [Accessed 25th June 2021].

2. Dahlquist GG, Nyström L, Patterson CC. Swedish Childhood Diabetes Study Group, \& Diabetes Incidence in Sweden Study Group. Incidence of type 1 diabetes in Sweden among individuals aged 0-34 years, 1983-2007: an analysis of time trends. Diabetes care. 2011; 34(8):1754-1759. doi:10.2337/dc11-0056

3. Sarwar N, Gao P, Seshasai SR, Gobin R, Kaptoge S, Di Angelantonio E, et al. Diabetes mellitus, fasting blood glucose concentration, and risk of vascular disease: a collaborative meta-analysis of 102 prospective studies. Lancet (London, England). 2010; 375(9733):2215-2222. doi:10.1016 /S0140-6736(10)60484-9

4. Rao Kondapally Seshasai S, Kaptoge S, Thompson A, Di Angelantonio E, Gao P, Sarwar N, et al. Emerging Risk Factors Collaboration. Diabetes mellitus, fasting glucose, and risk of causespecific death. The New England journal of medicine. 2011; 364(9):829-841. doi:10.1056/NEJM oa1008862

5. Centers for Disease Control and Prevention. Grow Charts, z score. Available from: www.cdc. gov/growthcharts/zscore.htm [Accessed 25th June 2021].

6. Pediatric and Fetal Echo Z-Score Calculators. Available from: http://parameterz.blogspot. com/2008/09/z-scores-of-cardiac-structures. html [Accessed 25th June 2021].

7. Lurbe E, Agabiti-Rosei E, Cruickshank JK, Dominiczak A, Erdine S, Hirth A, et al. European Society of Hypertension guidelines for the management of high blood pressure in children and adolescents. Journal of hypertension. 2016; 34(10):1887-1920. doi:10.1097/HJH.0000000 000001039

8. Flynn JT, Kaelber DC, Baker-Smith CM, Blowey D, Carroll AE, Daniels SR, et al. Clinical practice guideline for screening and management of high blood pressure in children and adolescents. $P e$ diatrics, 2017, 140(3). doi:10.1542/peds.20171904

9. Whelton PK, Carey RM, Aronow WS, Casey DE, Collins KJ, Dennison Himmelfarb, et al. ACC/ AHA/AAPA/ABC/ACPM/AGS/APhA/ASH/ASPC/ NMA/PCNA guideline for the prevention, detection, evaluation, and management of high blood

\section{ETHICAL APPROVAL}

The research was approved by the Research Ethics Committee of Nicolae Testemitanu State University of Medicine and Pharmacy (report no. 42 of 17.06.2019).

pressure in adults: a report of the American College of Cardiology/American Heart Association Task Force on Clinical Practice Guidelines. Journal of the American College of Cardiology, 2017; 71(19), e127-e248.

10. DiMeglio LA, Acerini CL, Codner E, Craig ME, Hofer SE, Pillay K, Maahs DM. ISPAD Clinical Practice Consensus Guidelines 2018: glycemic control targets and glucose monitoring for children, adolescents, and young adults with diabetes.

11. Diabetul zaharat necomplicat, Protocol clinic național (PCN-33), 2017. Available from: http:// 89.32.227.76/_files/15516-PCN-33\%2520DZ. pdf [Accessed 25th June 2021].

12. Lopez L, Colan SD, Frommelt PC, Ensing GJ, Kendall K, Younoszai AK, et al. Recommendations for quantification methods during the performance of a pediatric echocardiogram: a report from the Pediatric Measurements Writing Group of the American Society of Echocardiography Pediatric and Congenital Heart Disease Council. Journal of the American Society of Echocardiography. 2010; 23(5):465-495.

13. Hietalampi H, Pahkala K, Jokinen E, Rönnemaa T, Viikari JS, Niinikoski $H$, et al. Left ventricular mass and geometry in adolescence: early childhood determinants. Hypertension. 2012; 60(5): 1266-1272. doi:org/10.1161/HYPERTENSIONA HA.112.194290

14. Khoury PR, Mitsnefes M, Daniels SR, Kimball TR. Age-specific reference intervals for indexed left ventricular mass in children. Journal of the American Society of Echocardiography. 2009; 22(6):709-714. doi:10.1016/j.echo.2009.03.003

15. Alp H, Karaarslan S, Eklioglu BS, Atabek ME, Baysal T. The effect of hypertension and obesity on left ventricular geometry and cardiac functions in children and adolescents. Journal of hypertension. 2014; 32(6):1283-1292. doi:10.1097 /HJH.0000000000000176

16. World Health Organization. Data and statistics. Available from: https://www.euro.who.int /en/health-topics/noncommunicable-diseases/ cardiovascular-diseases/data-and-statistics [Accessed 25th June 2021].

17. Hamman RF, Bell RA, Dabelea D, D'Agostino RB, Jr Dolan L, Imperatore G, et al. The SEARCH for Diabetes in Youth study: rationale, findings, and future directions. Diabetes care. 2014; 37(12):3336-3344. doi:10.2337/dc14-0574 
Skali H, Shah A, Gupta DK, Cheng S, Claggett B, Liu J, et al. Cardiac structure and function across the glycemic spectrum in elderly men and women free of prevalent heart disease: the Atherosclerosis Risk In the Community study. Circulation: Heart Failure. 2015; 8(3):448-454.

doi:10.1161/CIRCHEARTFAILURE.114.001990

White NH, Sun W, Cleary PA, Tamborlane WV, Danis RP, Hainsworth DP, Davis MD. and DCCT-EDIC Research Group. Effect of prior intensive therapy in type 1 diabetes on 10-year progression of retinopathy in the DCCT/EDIC: comparison of adults and adolescents. Diabetes. 2010; 59(5):1244-1253. doi:10.2337/db09-1216

Ogugua CF, Chikani UN, Ibekwe MU, Ngwieri T, Allen H. Early signs of microvascular complications in pediatric patients with short duration of type 1 diabetes mellitus seen in Southeast Nigeria. Annals of African medicine. 2019;18(4):200. doi:10.4103/aam.aam_5_19

Aljuhani F, Al-Agha A, Almunami B, Meftah EA, Sultan RA, Sultan RA, et al. Growth status of children and adolescents with type 1 diabetes mellitus in Jeddah, Saudi Arabia: a cross-sectional study. Curr Pediatr Res. 2018; 22(3): 249-254.

Stankute I, Dobrovolskiene R, Danyte E, RazanskaiteVirbickiene D, Jasinskiene E, Mockeviciene G, et al. Factors affecting cardiovascular risk in children, adolescents, and young adults with type 1 diabetes. Journal of Diabetes Research. 2019. doi:10.1155/2019/9134280

Redondo MJ, Foster NC, Libman IM, Mehta SN, Hathway JM, Bethin KE, et al. Prevalence of cardiovascular risk factors in youth with type 1 diabetes and elevated body mass index. Acta diabetologica. 2016; 1;53(2):271-7. doi:10.1007/ s00592-015-0785-1

Eilander M, de Wit M, Rotteveel J, Snoek FJ. Low selfconfidence and diabetes mismanagement in youth with type 1 diabetes mediate the relationship between behavioral problems and elevated HbA1c. Journal of diabetes research. 2016. doi:10.1155/2016/3159103

Date of receipt of the manuscript: 29/06/2021 Date of acceptance for publication: $25 / 12 / 2021$

Valeriu ESANU, ORCID ID: 0000-0001-9058-0317 Ina PALII, ORCID ID: 0000-0002-4320-2951
Bagheri MM, Maleki E, Mehrizi SR, Dehghani A. Investigating the relation between hemoglobin A1C to left ventricular Hypertrophy and left ventricle mass in children with type 1 diabetes mellitus. 2018.

Seferovic JP, Tesic M, Seferovic PM, Lalic K, Jotic A, Biering-Sørensen T, et al. Increased left ventricular mass index is present in patients with type 2 diabetes without ischemic heart disease. Scientific reports. 2018; 8(1):1-7. doi:10.1038/ s41598-018-19229-w

Abd El Dayem SM, Battah AA. Effect of glycemic control on the progress of left ventricular hypertrophy and diastolic dysfunction in children with type I diabetes mellitus. Anadolu Kardiyol Derg. 2012; 12:498507.

Weinrauch LA, Burger AJ, Aronson D, Gleason RE, Lee AT, D'Elia JA. Regression of left ventricular hypertrophy in diabetic nephropathy: loss of parasympathetic function predicts response to treatment. The Journal of Clinical Hypertension. 2006; 8(5):330-5. doi:10.1111/j.1524-6175. 2005.04771.x

Skali H, Shah A, Gupta DK, Cheng S, Claggett B, Liu J, et al. Cardiac structure and function across the glycemic spectrum in elderly men and women free of prevalent heart disease: the Atherosclerosis Risk In the Community study. Circulation: Heart Failure. 2015; 8(3):448-54.

doi:10.1161/CIRCHEARTFAILURE.114.001990

Velagaleti RS, Gona P, Chuang ML, Salton CJ, Fox CS, Blease SJ, et al. Relations of insulin resistance and glycemic abnormalities to cardiovascular magnetic resonance measures of cardiac structure and function: the Framingham Heart Study. Circulation: Cardiovascular Imaging. 2010; 3(3):257-63. doi:10.1161/CIRCIMAGING.109. 911438

Yilmaz S, Canpolat U, Aydogdu S, Abboud HE. Diabetic cardiomyopathy; summary of 41 years. Korean circu$\begin{array}{lll}\text { lation journal. 2015; 45(4):266. } & \end{array}$ doi:10.4070/kcj.2015.45.4.266

Stakos DA, Schuster DP, Sparks EA, Wooley CF, Osei K, Boudoulas H. Cardiovascular effects of type 1 diabetes mellitus in children. Angiology. 2005; 56(3):311-7. doi:10.1177/000331970505 600311 